\title{
Choroba Alzheimera - historia niepowodzeń - krótka opinia na temat współczesnego stanu badań
}

\section{dr hab. Dariusz Stępkowski ${ }^{\square}$}

Pracownia Molekularnych Podstaw Ruchów Komórkowych, Instytut Biologii Doświadczalnej im. M. Nenckiego PAN, Warszawa

https://doi.org/10.18388/pb.2019_284

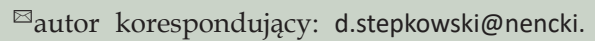
gov.pl

Słowa kluczowe: Choroba Alzheimera, demencja, $\beta$-amyloid, terapia

\section{STRESZCZENIE}

$\mathrm{O}$ opisania pierwszego przypadku choroby Alzheimera minęło ponad 110 lat. Pomimo intensywnych badań nad przyczynami tej choroby pozostaje ona w dalszym ciągu nieuleczalna. Znakomita większość badań klinicznych nad nowymi terapeutykami nakierowanymi na powstrzymanie niepożądanej agregacji $\beta$-amyloidu zawiodła. Wymaga to przemyślenia strategii zwalczania tej choroby od nowa. Wiele dowodów przemawia za utrzymaniem $\beta$-amyloidu jako centralnego obiektu patologii tej choroby, jednakże jego agregacja do większych supramolekularnych struktur jest zapewne etapem pośrednim, a nie przyczyną choroby. Wiele przemawia za tym, że we wczesnym okresie życia szereg stresów komórkowych prowadzi do zmian epigenetycznych skutkujących w późniejszych latach amyloidogenezą, a w jej następstwie do neurodegeneracji. Proces ten zajmuje dziesiątki lat trajektorii życia. Zatem ewentualne terapie powinny uwzględniać ten fakt i być stosowane już na wczesnym etapie życia i w przeciągu jego trwania. Rozpoznanie zmian epigenetycznych prowadzących do choroby Alzheimera powinno stanowić priorytet badań. Jeżeli ta koncepcja jest prawdziwa, daje nadzieję na odwrócenie zmian chorobowych.

Choroba Alzheimera po raz pierwszy została opisana w 1907 roku przez niemieckiego lekarza psychiatrę, Aloiza Alzheimera. Od tego czasu, pomimo upływu 112 lat pozostaje ona nieuleczalna, gdyż nie opracowano skutecznej terapii tej wyniszczającej choroby. Przewiduje się, że w roku 2030 liczba chorych na świecie osiagnie 70 milionów [1]. Postawienie diagnozy choroby Alzheimera jest wielkim dramatem zarówno dla pacjenta, jak i jego bliskich. Oznacza to bowiem postępujący ubytek zdolności do samodzielnego bytowania i konieczność - w późniejszych okresach choroby - stałej opieki. Średnia przeżywalność od momentu postawienia diagnozy w tej chorobie wynosi od 3 do 10 lat. Konieczność zapewnienia opieki i terapii generuje olbrzymie koszty dla rodzin i dla społeczeństwa. W 2015 roku oszacowano roczny, globalny koszt choroby Alzheimera na 818 miliardów dolarów amerykańskich [1]. Cechami charakterystycznymi choroby są: gromadzenie się złogów peptydu $\beta$-amyloidu w przestrzeniach międzykomórkowych mózgu oraz następnie tak zwanych splątków neurofibrylarnych białka Tau w cytoplazmie neuronów. Procesy te poprzedzają wystąpienie ubytków poznawczych u pacjentów. Według najbardziej uznawanej teorii przyczyn tej choroby (hipotezy kaskady amyloidowej) gromadzenie się złogów tych dwóch białek sekwencyjnie najpierw $\beta$-amyloidu, a później białka Tau, prowadzi do procesów neurodegeneracji i problemów demencyjnych. Znakomita większość badań nad nowymi lekami na tę chorobę była motywowana następującą logiką: jeżeli usuniemy przyczyny agregacji $\beta$-amyloidu, to usuniemy przyczynę neurodegeneracji. Niestety logika ta zawiodła oczekiwania. Warto zastanowić się nad przyczynami niepowodzeń badań nad nowymi terapiami choroby Alzheimera. Temat ten jest opisany szeroko przez McDade i Bateman [1] i Golde i wsp. [2] oraz Panza i wsp. [3]. Można go w skrócie podsumować tytułami odpowiednich artykułów: „Stop Alzheimer's before it starts” [1] i „Alzheimer's disease: The right drug, the right time" [2]. Autorzy tych dwóch artykułów, pomimo wszystkich niepowodzeń terapii nakierowanych na $\beta$-amyloid, są pełni jednak optymizmu. Ich zdaniem w odpowiednim czasie, kiedy jeszcze nie występują symptomy choroby, a nawet nie nagromadziły się jeszcze złogi $\beta$-amyloidu, możliwe będzie zastosowanie skutecznej terapii przeciwko nadprodukcji $\beta$-amyloidu w postaci „magicznego pocisku” molekularnego, którym może być pojedynczy związek chemiczny. Panza i wsp. [3] są bardziej ostrożni i chociaż nie negują całkowicie, że hipoteza kaskady amyloidowej jako głównej przyczyny choroby Alzheimera jest prawdziwa, to apelują o tworzenie nowych koncepcji przyczyn tej choroby. Rzeczywiście, biorąc pod uwagę, niepowodzenia wszystkich dotychczasowych badań klinicznych nad nowymi lekami na tę chorobę skierowanymi przeciwko $\beta$-amyloidowi w liczbie kilkudziesięciu [3], warto zastanowić się nad nowymi kierunkami terapii takimi, jak zwalczanie stanu zapalnego centralnego układu nerwowego, zahamowanie hiper fosforylacji białka Tau (a przez to jego agregacji), zniesienie oporności na insulinę w mózgu, 
zastosowanie leków przeciw wirusowych i przeciw bakteryjnych, czy też zwalczanie stresu oksydacyjnego [3,4]. Nowym kierunkiem terapii może tez być zwalczanie negatywnego wpływu $\beta$-amyloidu na krążenie krwi w naczyniach włosowatych w mózgu. Zjawisko to zostało opisane w 2019 roku przez Nortleya i wsp. [5], którzy sugerują, że mechanizmy naczyniowe mogą odgrywać szczególną rolę w patologii choroby Alzheimera.

Pomimo wszystkich niepowodzeń w opracowaniu nowych leków nakierowanych na $\beta$-amyloid, pozostaje on nadal centralnym obiektem zainteresowania $\mathrm{w}$ badaniach nad poznaniem przyczyn i opracowaniem skutecznych terapii choroby Alzheimera. Przemawia za tym wiele dobrze ugruntowanych wyników badań, zwłaszcza nagromadzenie mutacji genetycznych prowadzacych do powstania genetycznej odmiany choroby Alzheimera na szlaku prowadzącym do tworzenia $\beta$-amyloidu. $\beta$-amyloid zaczyna się gromadzić w mózgu około 15-20 lat przed wystąpieniem pierwszych objawów, zatem ewentualna terapia przeciwko jego gromadzeniu powinna być zastosowana odpowiednio wcześniej. Pojawia się pytanie, czy ta terapia powinna zmierzać do pełnego zahamowania produkcji $\beta$-amyloidu? W świetle badań wskazujących na fizjologiczną rolę $\beta$-amyloidu w procesach poznawczych [3 i pozostałe odnośniki w tym artykule] wydaje się, że potrzebne jest utrzymanie fizjologicznego stężenia tego peptydu, zapewniającego utrzymanie jego fizjologicznej funkcji, która może być związana z różnymi stanami agregacji - formą monomeryczną, oligomeryczną czy fibrylarną [6]

Osobiście jestem zwolennikiem koncepcji terapii wieloczynnikowej, nie ograniczającej się do stworzenia pojedynczego „magicznego pocisku” molekularnego. Ze względu na skomplikowaną etiologię choroby Alzheimera, a zwłaszcza biorąc pod uwagę, że najsilniejszym czynnikiem ryzyka jest tu proces starzenia organizmu, działanie dotyczące wielu węzłów sieci molekularnej w pojedynczych komórkach i na poziomie narządów oraz całego organizmu, wydaje się być jedyną sensowną alternatywą dla nieskutecznych mono terapii nakierowanych na ograniczenie agregacji $\beta$-amyloidu. To oczywiście nie oznacza, że ograniczanie patologicznej agregacji $\beta$-amyloidu z zachowaniem jego fizjologicznej roli nie powinno być fragmentem takiej terapii. Za terapią wieloczynnikową przemawiają też wyniki badań nad opracowaniem profilaktycznych działań w stosunku do zagrożenia tą chorobą. Obejmują one wieloczynnikowe działania w sferze diety, aktywności intelektualnej, fizycznej oraz społecznej i kulturalnej, które przekładają się na zmiany fizjologiczne organizmu sprzyjające opóźnieniu procesów starzenia i - co za tym idzie - postępu choroby Alzheimera, czy też bardziej ogólnie - demencji [patrz zeszyt Journal of Alzheimer's Disease, vol. 70, no. s1, International Research Network on Dementia Prevention, poświęcony profilaktyce choroby Alzheimera i demencji]. Wyniki naszych i przeprowadzonych przez innych badaczy analiz sugerują, że niezdrowa dieta ma swój spory udział w procesach prowadzących do choroby Alzheimera [7-9]. Studnicki i wsp. $[7,8]$ podzielili okres życia człowieka na cztery podokresy (młodość, wczesny wiek średni, późny wiek średni i wiek późny) i zaproponowali, że dla każdego z tych okresów potrzebna jest inna dieta, optymalna pod kątem składu ma- kroskładników tak, aby działać profilaktycznie zmniejszając ryzyko wystąpienia choroby Alzheimera. Z kolei Stępkowski i wsp. [10] zaproponowali, że najwcześniejsze okresy życia mają największy wpływ na późniejszą zapadalność na chorobę Alzheimera. Zgodnie z tą obserwacją działania profilaktyczne i ewentualną terapię wspomagającą należałoby rozpocząć już w dzieciństwie, zwłaszcza u osób o zwiększonej podatności genetycznej na tę chorobę. Obserwacja, że pierwszy okres życia ma największy wpływ na zapadalność na chorobę Alzheimera w starości sugeruje znaczny wpływ czynników epigenetycznych na rozwój tej choroby. Działają one powodując dyshomeostazę organizmu, prowadzącą do agregacji $\beta$-amyloidu, ogólnoustrojowego stanu zapalnego oraz agregacji białka Tau i - w następstwie tych procesów - do utraty połączeń synaptycznych i problemów $\mathrm{z}$ pamięcią $\mathrm{w}$ wyniku postępującej neurodegeneracji. Jeżeli za tę chorobę odpowiedzialne są zmiany epigenetyczne zachodzące $\mathrm{w}$ organizmie ludzkim $\mathrm{w}$ przebiegu trajektorii życia, to istnieje cień nadziei na skuteczną terapię. Z natury rzeczy zmiany epigenetyczne są odwracalne i teoretycznie można by cofnąć tak zwany „zegar epigenetyczny” (zespół zmian epigenetycznych $\mathrm{w}$ procesie starzenia organizmu) [11] lub przynajmniej go zatrzymać. Wspomniałem już o możliwych działaniach profilaktycznych poprzez stosowanie zdrowej diety, aktywność fizyczną, aktywność intelektualną, społeczną i kulturalną. Wszystkie te działania mają wpływ na stan epigenetyczny organizmu i „zegar epigenetyczny" $[12,13]$. Dokładne poznanie tych zmian w odniesieniu do choroby Alzheimera i innych chorób neurodegeneracyjnych pozwoli na bardziej precyzyjne działania zmierzające do ich odwrócenia. Oczywiście takie działania mogą być skuteczne zanim doszło do neurodegeneracji, czyli na wcześniejszych etapach rozwoju choroby. Natomiast na etapie kiedy zmiany neurodegeneracyjne już zaszły, prawdopodobnie możliwe jest zahamowanie postępu choroby. Innym ciekawym aspektem zmian epigenetycznych jest tak zwane "dziedziczenie epigenetyczne”. Procesy te są jeszcze słabo poznane, wiadomo jednak, że dziedziczenie epigenetyczne zachodzi poprzez komórki rozrodcze, które przenoszą "pamięć" o stresach komórkowych, jakim podlegały organizmy rodziców [14]. Istnieje prawdopodobieństwo, że dzisiejsza epidemia choroby Alzheimera ma pewien związek z historią życia generacji rodziców dzisiejszych pacjentów. Podobnie jak w przypadku "zegara epigenetycznego" teoretycznie możliwe jest cofnięcie tych zmian. Wciąż nie jest jasne, w jakim stopniu historia życia pokolenia rodziców ma wpływ na następne pokolenie, ale taka możliwość jest realna.

Podsumowując, ponad stuletnia historia badań nad chorobą Alzheimera jest zarówno pasmem sukcesów dotyczących rozpoznania procesów patologicznych i ich sekwencji w czasie, jak i niepowodzeń - tych ostatnich zwłaszcza w odniesieniu do możliwych działań terapeutycznych potencjalnymi lekami. Wymaga to nowego spojrzenia na procesy prowadzące do rozwoju tej choroby i zaproponowania nowych sposobów terapii i nowych potencjalnych leków.

\section{PIŚMIENNICTWO}

1. McDade E, Bateman RJ (2017) Stop Alzheimer's before it starts. Nature 547: 153-155. https://doi.org/10.1038/547153a 
2. Golde TE, DeKosky ST, Galasko D (2018) Alzheimer's disease: The right drug, the right time. Science 362: 1250-1251. https://doi. org/10.1126/science.aau0437

3. Panza F, Lozupone M, Logroscino G, Imbimbo BP (2019) A critical appraisal of amyloid- $\beta$-targeting therapies for Alzheimer disease. Nature Reviews Neurology 15: 73-88. https://doi.org/10.1038/s41582-0180116-6

4. Panza F, Lozupone M, Solfrizzi V, Watling M, Imbimbo BP (2019) Time to test antibacterial therapy in Alzheimer's disease. Brain: A Journal of Neurology. https:/ / doi.org/10.1093/brain/awz244

5. Nortley R, Korte N, Izquierdo P, Hirunpattarasilp C, Mishra A, Jaunmuktane $Z$ et al. (2019) Amyloid $\beta$ oligomers constrict human capillaries in Alzheimer's disease via signaling to pericytes. Science 365: eaav9518. https://doi.org/10.1126/science.aav9518

6. Puzzo D (2019) A $\beta$ oligomers: role at the synapse. Aging https:/ / doi. org/10.18632/aging.101818

7. Studnicki M, Woźniak G, Stępkowski D (2016) The calculator of anti-Alzheimer's diet. Macronutrients. PloS One 11: e0168385. https:/ / doi. org/10.1371/journal.pone.0168385

8. Studnicki M, Woźniak G, Stępkowski D (2018) Correction: the calculator of anti-Alzheimer's diet. Macronutrients. PLoS One 13: e0209723. https://doi.org/10.1371/journal.pone.0209723
9. GBD 2017 Diet Collaborators. (2019) Health effects of dietary risks in 195 countries, 1990-2017: a systematic analysis for the Global Burden of Disease Study 2017. Lancet (London, England) https://doi. org/10.1016/S0140-6736(19)30041-8

10. Stępkowski D, Woźniak G, Studnicki M (2015) Correlation of Alzheimer's disease death rates with historical per capita personal income in the USA. PloS One 10: e0126139. https:// doi.org/10.1371/journal. pone.0126139

11. Fahy GM, Brooke RT, Watson JP, Good Z, Vasanawala SS, Maecker H et al. (2019) Reversal of epigenetic aging and immunosenescent trends in humans. Aging Cell https://doi.org/10.1111/acel.13028

12. Vidrascu EM, Bashore AC, Howard TD Moore JB (2019) Effects of early- and mid-life stress on DNA methylation of genes associated with subclinical cardiovascular disease and cognitive impairment: a systematic review. BMC Medical Genetics, 20: https://doi.org/10.1186/ s12881-019-0764-4

13. Tzika E, Dreker T, Imhof A (2018) Epigenetics and Metabolism in Health and Disease. Frontiers in Genetics 9:361. https:/ / doi.org/10.3389/ fgene.2018.00361

14. Lacal I, Ventura R (2018) Epigenetic Inheritance: Concepts, Mechanisms and Perspectives. Frontiers in Molecular Neuroscience 11: 292 https://doi.org/10.3389/fnmol.2018.00292

\section{Alzheimer's disease - history of failures - a short opinion on the contemporary status of research}

\section{Dariusz Stępkowski}

Laboratory of Molecular Basis of Cell Motility, Nencki Institute of Experimental Biology, Warszawa, Poland

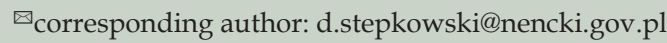

Key words: Alzheimer's Disease, dementia, $\beta$-amyloid, therapy

\section{SUMMARY}

Over 110 years have passed since first description of Alzheimer's disease (AD). Despite intensive research, AD remains incurable. The vast majority of clinical trials on new therapies aimed at suppressing undesirable aggregation of $\beta$-amyloid have failed. This requires rethinking of the strategy to fight AD. A lot of evidence supports the maintenance of $\beta$-amyloid as the central object of AD pathology, however, its aggregation into larger supramolecular structures is probably an intermediate stage and not the cause of the disease. In the early stages of life, cellular stresses lead to epigenetic changes resulting in later amyloidogenesis and subsequent neurodegeneration. This process takes decades of life trajectory. Therefore, possible therapies should take into account this fact and be applied early in the life and prolonged later. Diagnosis of epigenetic changes leading to AD should be a research priority. If this concept is true, it may give hope to reverse these changes. 